\title{
A Closer Look at Language Learning Strategies
}

\section{Joseph C. Wood \\ Nagoya Women's University}

\section{Reference Data:}

Wood, J. C. (2020). A closer look at language learning strategies. In P. Clements, A. Krause, \& R. Gentry (Eds.), Teacher efficacy, learner agency. Tokyo: JALT. https://doi.org/10.37546/JALTPCP2019-13

Language learning strategies (LLSs) are made up of the conscious and deliberate actions that language learners take in order to help them learn a language. It would be useful, however, to know which particular LLSs are the most effective so we can in turn focus on them in class and encourage our students to begin using them. To do this, we should ask ourselves, what kinds of LLSs do advanced-level students use in their own language learning? This study examined that question in hopes of learning the most effective strategies to teach our lower-level students to use. An advanced-level class of 18 second-year university students in Japan was surveyed on the effectiveness of LLSs based on a class-generated list. Following this, six students were selected for in-depth interviews. The survey and interview data found that students believed that speaking strategies are the most effective for learning English.

言語学習におけるストラテジー（LLSS)とは、学習者が言語を学びやすくするために起こす意識的かつ計画的な行動によ り構成されるものである。しかしながら、最も効果的なLLSSは何なのかを知ることは有益である。さらに授業の中でそれらの LLSSに注目し、学生たちがそれらを使い始めるように促すことを可能にするためである。それを知るために、私達は自分自身

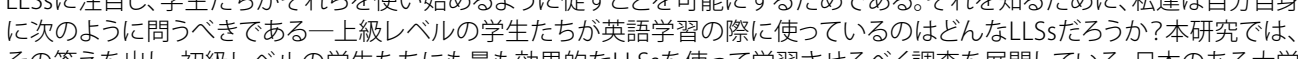

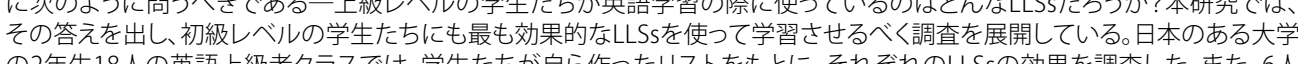

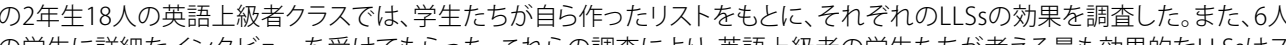

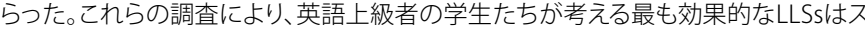
ピーキングであるということがわかった。

uccessful language learners are successful for a reason; they consciously incorporate strategies into their language learning in a way that maximizes it. These language learning strategies (LLSs) spring from the motivation to learn and can be as simple as making vocabulary flashcards or watching movies in the target language. The concept of LLSs became of interest to language teachers in the 1970s when Rubin (1975) published her groundbreaking paper, What the 'Good language Learner' Can Teach Us. Rubin continued to study and write about LLSs, but interest in the topic really took off and began a second, much stronger life in 1990 when two classic books were published, O'Malley and Chamot's Learning Strategies in Second Language Acquisition and Oxford's Language Learning Strategies: What Every Teacher Should Know. With these seminal books, a new interest in the area of LLSs emerged from the 1990s onward with Oxford (1996) editing an entire book dedicated to studies in the field of LLSs. Further books featuring collections of studies dedicated specifically to research in LLSs continued into the 2000s as well (Cohen \& Macaro, 2007).

Although the topic of LLSs continues to gain attention, there are still many unanswered questions and controversies concerning the phenomenon. For example, how can students' use of LLSs be assessed? How can data be more effectively collected from students concerning their use of LLSs? Should class time be used to teach students how to use LLSs? With questions like these yet to be fully answered, the need for further research remains. Griffiths (2013), contemplating the significance of Rubin's 1975 paper states that, "At the time, few people probably expected that it would sow the seeds of controversies which would still be unresolved several decades later" (p. x). Oxford and Schramm (2007) discussed the need to avoid a "paradigm war" over how LLSs are viewed by researchers, declaring it "unnecessary" and stating that it "could deny opportunities for synergy that might lead to more powerful and useful theory and research on learner strategies" (p. 49). Further controversies also continue to surround the ways in which students are trained to use LLSs. Plonsky (2011) stated, "although there is widespread agreement among language researchers and practitioners on the benefits of $\mathrm{L} 2$ strategies, there is much less agreement on how to foster a student's ability to employ strategies for language learning and use" (p. 998). From a purely observational viewpoint, it is clear 
that some language learners are indeed more successful than others. What is less clear, however, is why that is so. Macaro (2001) stated, "we must take care not to confuse successful language learners with advanced learners. While it is self-evident that the latter must have crossed a threshold of success, the advanced learning stage is not a necessary condition for effective strategy use" (p. 31). Clearly successful language learners must be doing something that less-successful learners are not doing. The answer is not always as simple as they just study more. The hope of the current study was to shed light on this issue by way of examining in detail what kinds of LLSs advanced learners used in the past to get to the level they are at now as well as what kinds of strategies they currently use to maintain or improve that level. In essence, this study examined how these learners became so successful at learning English as a foreign language in the modern era where new LLSs that involve technology play such a vital role.

\section{Definitions}

Oxford (1990) stated simply that LLSs were "steps taken by students to enhance their learning" (p. 1). Therefore, we can interpret this to mean that LLSs are conscious and purposeful actions taken by learners to increase their chances of successfully learning their target language. Chamot (2004) added, "Strategic learners have metacognitive knowledge about their own thinking and learning approaches, a good understanding of what a task entails, and the ability to orchestrate the strategies that best meet both the task demands and their own learning strengths" (p. 14). Chamot mentioned "metacognitive knowledge," leading us to believe that self-awareness and understanding of our way of learning is an important part of using LLSs. Rubin (1975) stated, "We all know of students who learn a second language in spite of the teacher, the textbook, or the classroom situation" (p. 42). She immediately followed up her statement with a logical question, "How do these individuals achieve their success?" (p. 42). Rubin sought to learn what successful students were doing in the 1970s and the current study sought to understand what they are doing currently, almost a half century later.

\section{Method}

\section{Participants and Context}

Participants in this study consisted of 18 English majors at a Japanese university who were in the top class of a streamed English program within the Department of British and American Studies. All 18 students were Japanese native speakers who were highly proficient in speaking English. These students were able to discuss complex topics in the language as well as express their opinions on a variety of discussion topics covered in class with relative ease. Due to these students being streamed by language proficiency and placed in the "Advanced" class, this study refers to them as "advanced learners" instead of what could be the more appropriate term, "successful learners."

The course was an advanced-level four skills course, but due to the level of the students, more emphasis was put on critical thinking and discussions in the target language. Although the textbook used for the class was written for advanced learners, often times more difficult material was brought into class to challenge the students since at times the textbook appeared too easy for many of them (i.e. news articles in English, podcast listening activities, etc.). It is also useful to note here that the instructor had no control over the textbook due to another instructor's role as coordinator for this specific class. The students were quite motivated learners and as the first semester moved along, the instructor became curious as to how these particular students, of whom only a handful had ever been abroad before, were able to become so proficient in English as a foreign language.

\section{Research Questions}

For the current study, two research questions were examined:

1. What LLSs do successful learners use to learn English?

2. Out of these LLSs, which ones do they believe are the most effective in learning the language?

\section{Data Collection}

The instructor raised the topic of LLSs with the class and asked if they had ever heard the phrase before. Out of the 18 students, 11 had heard of LLSs. After some students showed confusion about LLSs, examples were given as well as a brief definition. At this point, students who initially reported that they had never heard of LLSs, reported that they did in fact know what they were, but had never heard them described as "language learning strategies" before.

Following this discussion and explanation of LLSs, the instructor asked the students to work in pairs and to discuss the various LLSs that they knew about or had used themselves while learning English. After students discussed their knowledge and personal use of LLSs, the instructor asked them to work together and write down a list of the LLSs they had talked about with their classmates. Students were given 10 minutes to work with their partners on their lists, which were then collected by the instructor. 
After these lists were collected, the instructor used them to create a student-generated survey of LLSs. The most commonly reported LLSs were used to create a Likert scale survey asking the students to rank the usefulness of each LLS they and their classmates had listed (see Table 1 for the top five most useful LLSs according to the students). The scale asked students how useful each LLS was out of a $1-4$ ranking $(1=$ Not useful, 2 = A little useful, $3=$ Useful, and $4=$ Very useful). See Appendix for all 26 LLSs featured on the student-generated list and their usefulness based on survey results.

Table 1. Averages of the Top Five LLSs

\begin{tabular}{lll}
\hline 1. & Talking with English speakers: & 3.9 \\
2. Making friends with foreign students: & 3.8 \\
3. Making friends from other countries: & 3.8 \\
4. Watching movies with English subtitles: & 3.7 \\
5. Repeating what characters say in English movies: & 3.6
\end{tabular}

The surveys were collected and analyzed by the instructor, and interview questions were formed based on students' answers. Afterwards, six of the more proficient students were asked to participate in interviews with the instructor in which they would be asked more in-depth questions about their language learning history and the role that LLSs had played in it. These students gave the instructor their consent to be interviewed and recorded for research purposes knowing that their recordings would not be listened to by anyone else and that their real names would not be used in the case of the data being published. Interviews were conducted in English and lasted for an average of around 15 minutes per student. Although a set of interview questions were created beforehand and structured interviews were planned, due to students' level of speaking ability in English and their desire to discuss other issues outside the original questions, the interviews became semi-structured instead which ultimately led to even more in-depth interview data being collected. According to Cohen and Scott (1996), "Unstructured or semistructured interviews have the advantage of allowing the researcher and learners to pursue topics of interest which may not have been foreseen when the questions were originally drawn up" (p. 91).

Data Analysis

By looking at the survey data we were able to see that these particular advanced-level learners found more value in strategies that involved actual communication in the target language. That is to say, they prefered to learn in a less passive way. We could see this by examining the three-top ranked LLSs presented in Table 1 (Talking with English speakers, Making friends with foreign students, and Making friends from other countries). LLSs that

involved reading or writing tended to get lower rankings from students in terms of their usefulness (see Appendix for details). In interviews, however, some students spoke highly of such LLSs.

The following section will address the examination and analysis of the data from the interviews. It is important to add here that students' real names have not been used in the interview data featured in this paper. From the interview data, five themes emerged: Actively using the language is important, technology is a useful tool for language learning, watching movies or TV programs in the target language is a helpful way to learn it, reading and writing strategies are important, and focusing too much on grammar can actually have a negative impact on learning.

\section{Actively Using the Language Is Important}

Kenta reported that he made a lot of friends with the foreign students on campus and made an effort to speak English with them. "I made a lot of friends with this school's exchange students and I tried to speak English with them" (Kenta). According to Kumiko and Mika, they also both had foreign friends that they talked to in English. Kumiko talked with her English-speaking friends everyday. According to her, "I chat with my foreign friends everyday and I want to tell my opinion to them. I learn better at home, not from studying, just talking with foreign friends on the phone" (Kumiko). Mika felt she could improve her pronunciation by talking to her American friend. In her words, "I talked with my American friend a lot... Three times a week we meet and we talk more than one hour each time. I could get a good pronunciation. Like, maybe I have an American accent" (Mika). Chika reported that she was able to practice using her English with foreign customers at her work. According to her, "The best way [to learn English] is by talking with native speakers. At my part-time job, a lot of foreigners come, so I sometimes can talk with customers who are native speakers. So, it's a good challenge for me" (Chika).

\section{Technology Is a Useful Tool for Language Learning}

The interview data provided many insights into students' attitudes towards technology and how useful it was for learning a language. Miku, Taku, and Fumi all used technology to help improve their English, but they used it in different and interesting ways. Mika 
used her smartphone to study English. According to her, "Sometimes I talk to my phone. I record myself reading my [English] diary and some of my feelings" (Mika). Taku liked to listen to podcasts and watch YouTube videos. As he explained it, "I have many strategies to study English. I have podcasts and YouTube and TED on my iPhone. And I have, almost everyday I watch them, TED or YouTube or Bilingual News" (Taku). Fumi also reported that she used YouTube to study the language. "On YouTube recently I research make-up tutorials. l've used it because it's fun and can know the girls' information abroad. Because of these videos, I can learn about strategies about how to speak, how to explain things" (Fumi).

Watching Movies or TV Programs in the Target Language Is a Helpful Way to Learn it

When it came to watching movies or TV programs in English, students found it beneficial to their language learning. Fumi and Kumiko both liked to watch while also reading the English subtitles. "I really like Disney, so I like watching movies in English with English subtitles" (Fumi). "I like to watch movies with English subtitles" (Kumiko). Kenta also watched movies to study English, but prefered not to use subtitles and instead tried to repeat and memorize what the characters said. As he explained it, "Now, I just watch movies and try to repeat and memorize. No subtitles" (Kenta).

\section{Reading and Writing Strategies Are Important}

As for reading and writing strategies, students reported using various kinds in order to help facilitate their English learning. Taku and Miku both read aloud and believe it helped them. Taku felt that "reading is really good because I read aloud and it's a really good method" (Taku). Miku reported that she read aloud at home and sometimes recorded it on her smartphone. According to her, "I read aloud in my house. It helps me understand. I want to brush up on my pronunciation, so I often do it. Sometimes I record myself on my iPhone. I check my voice" (Miku). Fumi, however, prefered to write in English everyday. She wrote in a diary and on social media. In her words, "I like writing, so everyday I write in a diary, in my notebook, and on SNS, like Instagram...I try to show my friends or family my English and some people correct my English. I'm motivated by them" (Fumi).

Focusing Too Much on Grammar Can Actually Have a Negative Impact on Learning

Lastly, we will highlight students' beliefs about focusing too much on grammar and how it can hinder one's learning of English. Kumiko, Mika, and Kenta all believed that they learned English better by actually focusing less on grammar and more on just trying to communicate. In essence, comprehensible output was more important to them than accuracy. According to Kumiko, "I think Japanese care about grammar so much and they don't want to make mistakes when they are chatting with foreigners, so I think to care about grammar is not so good" (Kumiko). Mika explained that instead of worrying about grammar she just wanted to express her feelings and speak the language. According to her, "I don't care about grammar and just explain or express my feelings and just speak" (Mika). Kenta felt grammar was not useful during conversations. The way he saw it, "As a basic skill to use English, grammar is so important, but in conversations and in real situations, it's not useful. When I first started to speak English for the first time, I always took care of grammar and it took a long time to speak. It was terrible" (Kenta).

\section{Discussion}

Based on the survey and interview data, we could see that advanced-level students were conscious of when and how they used LLSs in order to help them learn English. In effect, we can call their use of LLSs conscious and purposeful. Although advanced learners may not need to use LLSs as often as they used to when they began to learn the language, the interview data featured in this study showed that these students were still continuing to use certain LLSs to either maintain their level or to improve it. Furthermore, it could be argued that by simply brainstorming LLSs with their classmates and creating lists, these advanced learners were able to raise their awareness of how they used LLSs before they took the survey or were interviewed.

The survey data showed that students appeared to believe that the best strategy for learning English was to actively use it. They looked for opportunities and made friends with native speakers in order to provide themselves with more chances to speak the language. Reading, writing, and listening strategies scored lower than speaking activities on the survey. One of the takeaways from the survey data was that many of these particular students did not believe in passive learning.

Based on the interview data, we could see that when students did not have someone to speak the language with, they often supplemented their learning of it by writing in journals at home, watching movies with or without subtitles, recording themselves speaking English on their smartphones, using English on social media, and employing many other interesting and creative ways to use or study the language. Furthermore, students felt that putting too much stress on grammar actually placed a hindrance on their learning. Shyer students may not speak in English class due to their fear of making 
mistakes with their grammar use. These learners may prefer more passive LLSs such as reading books or watching movies in the target language or taking notes in class as the teacher talks. The more outgoing students in this class got to the level they were at partly due to their motivation and excitement to use the language even if they were not completely confident in their grammar ability. These extroverts were more comfortable using social-based LLSs than the shyer students and by doing so potentially gained more experience actually speaking the language with others both inside and outside of class. Both the survey and interview data showed the importance of actively learning through interactions in the language.

An important point to take into consideration is that these findings may not be applicable to all groups of English learners. There is no one-size-fits-all LLS. Students who are majoring in English are much more likely to have a stronger motivation to learn the language and therefore may rely on different or more advanced LLSs to do so. For nonEnglish majors, LLSs that cater to their particular needs may be a better use of class time. If students are merely taking an English course as a credit requirement and speaking is not an important part of the course's grade, teaching students to use reading or writing LLSs may help them more in their goal of simply passing the class and gaining general knowledge of the language. LLS training should be crafted with your own classroom and students' objectives in mind. If your students are planning to study abroad, LLSs that deal with output or listening may be more important to them. The takeaway is that teachers should have a good idea of why their particular classes are learning English and should be able to select certain LLSs to teach that can help their students achieve their specific goals, whatever they may be.

\section{Conclusion}

Although the various strategies students reported using in this study to learn English might seem like obvious steps to take when learning a language, we must realize that for our lower-level learners, these strategies are not obvious steps to take at all. It will be of great benefit to our lower-level students if we can learn from more advanced learners and share the LLSs that helped them to get to where they are. We must also keep in mind that our students are busy and have lives of their own outside of the classroom. Their minds may not be focused on finding the best ways to learn English after the class bell rings and they leave the classroom. If we give them advice and LLS training in the classroom though, many students may be able to continue using those strategies outside the class and some may even begin to think of new ones they could use to help them learn better. According to Chamot (2004), "current models of language learning strategy instruction are solidly based on developing students' knowledge about their own thinking and strategic processes and encouraging them to adopt strategies that will improve their language and learning" (p. 21). However, not all educators are proponents of using valuable class time to teach students to use LLSs. Some educators may simply feel that LLSs are inherent and that learners will employ them on their own without being encouraged to do so. As Griffiths (2013) stated, "Although, according to cognitive theory, language learning strategies are learnable and teachable, much controversy remains over the issue of strategy instruction" (p. 145).

Based on the data collected and analyzed for this study, it appears that the students believed that LLSs played an important and useful role in their learning of English. If teachers want to equip their students with more tools to help them in learning English as a second or foreign language, using class time to actively teach them to use LLSs could be a useful and productive avenue to take. While it may be possible for some students to improve their use of LLSs simply by raising their awareness of them, classes as a whole could benefit from explicit LLS training by their instructor in the classroom. In order for strategy training to be effective, however, students should be given enough time to fully understand how they use the strategies and why (Plonsky, 2011). As teachers, it is our job to take a good look at our classrooms and try our best to assess what it is that our students need in order to help them achieve success. Then we must give them enough time and practice to do it.

\section{Bio Data}

Joseph C. Wood is currently an associate professor at Nagoya Women's University as well as president of the Nagoya JALT Chapter. His research interests include strategy training, extensive reading, and a few other things. < dearjoewood@gmail.com>

\section{References}

Chamot, A. (2004). Issues in language learning strategy research and teaching. Electronic Journal of Foreign Language Teaching, 1(1), 14-26.

Cohen, A. D., \& Macaro, E. (Eds.) (2007). Language learner strategies: Thirty years of research and practice. Oxford: Oxford University Press.

Cohen, A. D., \& Scott, K. (1996). A Synthesis of approaches to assessing language learning strategies. In Rebecca L. Oxford (Ed.), Language learning strategies around the world: Crosscultural perspectives (pp. 89-106). Honolulu: University of Hawai'i, Second Language Teaching \& Curriculum Center. 
Griffiths, C. (2013). The strategy factor in successful language learning. Bristol: Multilingual Matters. https://doi.org/10.21832/9781847699428

Macaro, E. (2001). Learning strategies in foreign and second language classrooms. London: Continuum.

O'Malley, J. M. \& Chamot, A. U. (1990). Learning strategies in second language acquisition. Cambridge: Cambridge University Press. https://doi.org/10.1017/CBO9781139524490

Oxford, R. L. (1990). Language learning strategies. Boston: Heinle and Heinle Publishers.

Oxford, R. L. (Ed.) (1996). Language learning strategies around the world: Cross-cultural perspectives (pp. 89-106). Honolulu: University of Hawai'i, Second Language Teaching \& Curriculum Center.

Oxford, R. L. \& Schramm, K. (2007). Bridging the gap between psychological and sociocultura perspectives on L2 learner strategies. In A.D. Cohen \& E. Macaro (Eds.), Language learner strategies: Thirty years of research and practice (pp. 47-68). Oxford: Oxford University Press.

Plonsky, L. (2011). The effectiveness of second language strategy instruction: A meta-analysis. Language Learning, 61(4), 993-1038. https://doi.org/10.1111/j.1467-9922.2011.00663.x

Rubin, J. (1975). What the 'good language learner' can teach us. TESOL Quarterly, 9 (1), 41-51. https://doi.org/10.2307/3586011

Appendix

Student-Generated Survey on LLSs and Averages of Answers Ranked

\begin{tabular}{|c|c|c|c|}
\hline LLS & $\begin{array}{l}\text { How useful } \\
1-4 \\
\text { Mean score }\end{array}$ & LLS & $\begin{array}{c}\text { How useful } \\
1-4 \\
\text { Mean score }\end{array}$ \\
\hline
\end{tabular}

\section{Talking with English \\ speakers}

2. Making friends with

foreign students

3.8

14. Writing English

3.3

sentences

summarizing interests in

English

3. Making friends from other countries

3.8 16. Reading the news in

English

4. Watching movies with

English subtitles

5. Repeating what

3.6

17. Reading English books

characters say in movies

18. Watching TED talks online

\begin{tabular}{|c|c|c|c|}
\hline LLS & $\begin{array}{l}\text { How useful } \\
1-4 \\
\text { Mean score }\end{array}$ & LLS & $\begin{array}{l}\text { How useful } \\
1-4 \\
\text { Mean score }\end{array}$ \\
\hline $\begin{array}{l}\text { 6. Memorizing phrases, } \\
\text { not only words }\end{array}$ & 3.5 & $\begin{array}{l}\text { 19. Listening to English } \\
\text { podcasts }\end{array}$ & 3.1 \\
\hline $\begin{array}{l}\text { 7. Memorizing phrases the } \\
\text { teacher says }\end{array}$ & 3.5 & $\begin{array}{l}\text { 20. Talking to yourself in } \\
\text { English (practicing alone } \\
\text { at home) }\end{array}$ & 3.0 \\
\hline $\begin{array}{l}\text { 8. Writing down new } \\
\text { words that you don't know } \\
\text { the meaning of }\end{array}$ & 3.4 & $\begin{array}{l}\text { 21. Writing down lyrics } \\
\text { while listening to English } \\
\text { music }\end{array}$ & 3.0 \\
\hline $\begin{array}{l}\text { 9. Getting a foreign } \\
\text { boyfriend or girlfriend }\end{array}$ & 3.4 & 22. Extensive reading & 2.9 \\
\hline $\begin{array}{l}\text { 10. Writing daily in an } \\
\text { English diary/journal }\end{array}$ & 3.4 & $\begin{array}{l}\text { 23. Listening to English } \\
\text { songs }\end{array}$ & 2.9 \\
\hline $\begin{array}{l}\text { 11. Watching English } \\
\text { movies }\end{array}$ & 3.4 & $\begin{array}{l}\text { 24. Listening to English } \\
\text { speakers on the train }\end{array}$ & 2.5 \\
\hline $\begin{array}{l}\text { 12. Contacting/Making } \\
\text { foreign friends on social } \\
\text { media }\end{array}$ & 3.4 & $\begin{array}{l}\text { 25. Following English } \\
\text { speaking celebrities on } \\
\text { Twitter }\end{array}$ & 2.5 \\
\hline $\begin{array}{l}\text { 13. Writing essays in } \\
\text { English }\end{array}$ & 3.3 & $\begin{array}{l}\text { 26. Chatting with Siri on } \\
\text { your iPhone }\end{array}$ & 2.2 \\
\hline
\end{tabular}

